\title{
Customs Unions and Free Trade Areas
}

\author{
Kimberly A. Clausing \\ Reed College
}

\begin{abstract}
This paper compares free trade areas and customs unions in terms of their potential to liberalize trade. While neither arrangement is shown to be unambiguously preferable, this paper generates specific conditions that determine when customs unions are preferred to free trade areas. The ranking of the two arrangements depends on how common external tariffs are set in customs unions, the restrictiveness of rules of origin in free trade agreements, and the original tariff levels among the member countries.
\end{abstract}

* JEL Classification: F13

- Key Words: Customs Unions, F ree Trade Areas, Rules of Origin

*Correspondence Address: Department of Economics,

Reed College, 3203 SE Woodstock Blvd, Portland. OR 97202-8199 U.S.A. (Tel)(503)771-1112, x7388, (E-mail)clausing@reed.edu.

Acknowledgments ; This work has been supported in part by a $\mathrm{N}$ ational Science Foundation Graduate Fellowship. I am grateful to James Hines, D onald Davis, and participants at Harvard University's international economics workshop for helpful comments.

(C) 2000 - Center for International Economics, Sejong Institution. All rights reserved. 


\section{Introduction}

Preferential trading agreements are growing rapidly, in both size and number. An incomplete inventory of recent initiatives includes proposals to extend NAFTA to Chile, to create a Free Trade Area of the Americas encompassing the entire Western Hemisphere, to establish free trade among the APEC nations, and to continue the expansion of the EU to other European countries. As preferential agreements expand, policy makers have become increasingly concerned with how best to design such agreements. An essential part of this deliberation has involved the choice between a customs union and a free trade area.

The sole technical distinction between a customs union and a free trade area is the presence of a common external tariff in the case of a customs union. In a free trade area, countries maintain their own external tariff regimes. However, this necessitates measures to avoid transshipment, so that a free trade area does not effectively become a customs union where the common tariff for each good is equal to the lowest member country tariff. ${ }^{1}$ Rules of origin (ROOs) specify a requirement that must be met in order for a particular good to originate in a given country or area, and hence to receive preferential tariff treatment. ${ }^{2}$

M ost of the work on free trade areas and customs unions analyzes these arrangements relative to multilateral liberalization, or relative to the status quo. The distinction between free trade areas and customs unions has not received much attention in the literature. However, two important papers by Krueger $(1993,1997)$ have drawn attention to this issue. Krueger (1993) examines the effects of rules of origin, arguing that rules of origin lead to exported protection. Building on this argument, Krueger (1997, p.171) argues that "on welfare grounds, a free trade agreement can yield no bene-

1. While such an outcome could be delightful from an economist's perspective, policy makers in high tariff countries may disagree.

2. As noted in Krueger and Krishna (1995), "from a legal point of view, there appear to be four alternative criteria. These are (a) requirements in terms of domestic content, (b) requirements in terms of a change in tariff heading, (c) requirements in terms of specified processes that must be performed within the FTA or CU; and (d) requirements that the product has been "substantially transformed." 
fits that are not attainable under a customs union, and can generate additional welfare costs that are not incurred under a customs union. Therefore, all else equal [emphasis added], customs unions are strictly Pareto superior to free trade agreements."

In this paper, I further discuss the welfare ranking of customs unions and free trade areas. I generate several conditions that determine when customs unions (CUs) are prefer red to free trade areas (FTAs). ${ }^{3}$ First, I analyze how the level at which the common external tariff is set under a customs union influences the desirability of CUs relative to FTAs. I find that when the common external tariff under a customs union is set at the average of the member countries' previous tariff levels, it is likely to lead to a less distortionary outcome than if the member countries had maintained their prior tariff levels.

Second, I study the effects of rules of origin (ROOs), finding that FTAs with nonuniform tariffs accompanied by ROOs have both advantages and disadvantages relative to the $\mathrm{CU}$ alternative. FTAs with ROOs may lead to both exported protection and exported liberalization. Which effect predominates depends on the restrictiveness of the ROOs as well as the tariff levels among the member countries.

While neither customs unions nor free trade areas are unambiguously preferable, this paper illuminates the essential trade-offs that policy makers should contemplate when they decide between a customs union and a free trade area. Through a better understanding of the trade-offs involved, it is possible to assess some of the costs and benefits of these two methods of liberalizing trade between countries.

Section II considers how the determination of the common external tariff in a CU affects a comparison of CUs and FTAs. Section III considers how rules of origin influence the comparison. Section IV presents some addition-

3. I will be assuming throughout the paper that the ideal outcome is one of maximum liberalization. This abstracts from several considerations, including the possibility for an optimal tariff to exploit the market power of a country or region. One can assume that countries are small, and hence unable to exploit optimal tariffs. An alternative option is to consider the impact of these preferential arrangements on the world as a whole, in which case nationalistic arguments in favor of higher tariffs would not pertain. 
al political economy considerations, and Section V concludes.

\section{Tariff Setting}

When analyzing FTAs and CUs, it is often assumed that external protection after the agreement remains the same as before the agreement. For a free trade area, this is equivalent to stating that the external tariffs for each country remain at their previous level. For a customs union, it is less clear what is being assumed. For example, maintaining the previous level of external protection in a customs union will not necessarily entail a common average external tariff for each good. ${ }^{4}$ It is clear that if customs unions were to set their external tariff equal to the highest of the member country tariffs, that would not only be GATT illegal, but also inferior to the outcome under an FTA. Similarly, if the common external tariff were set at the lowest of the member country tariffs, that would be superior to an FTA. At what point, however, would one be indifferent between the two ar rangements?

I will show that tariff averaging typically lowers distortions more than if each country had maintained their own prior tariffs. A tariff on a good creates deadweight loss equal to:

$$
\frac{1}{2} t^{2} P Q_{d} \quad d
$$

where $\epsilon_{\varepsilon}$ is the elasticity of (compensated) import demand, $\mathrm{P}$ and $\mathrm{Q}$ are price and quantity, and $t$ is the ad valorem tariff rate. If two otherwise identi -

4. Legally, GATT law has interpreted article XXIV such that the tariff incidence under a customs union should not be higher than the average overall incidence of the former constituent territories. Incidence is interpreted not in terms of burden but rather as augmenting a straightforward tariff average with a consideration of the volume of trade involved. Thus, the intent of GATT law is typically interpreted as requiring the overall tariff levels to be similar to a trade weighted average of previous tariffs. Nonetheless, in the actual formation of trade agreements, countries have often neglected to meet this criteria fully. For instance, in the case of Europe, it was concluded that "the incidence of the common tariff was higher than that of the rates actually applied by the member states at the time of the entry into force of the Treaty of Rome." (World Trade Organization(1995)) Similar protests have been frequent as other countries join the EU, and in the case of other customs unions. 
cal countries $a$ and $b$ form a free trade agreement, the deadweight loss in $a$ particular market due to their tariffs on the rest of the world is ${ }^{5}$ :

$$
\frac{1}{2} t_{a}^{2} P Q_{d d}+\frac{1}{2} t_{b}^{2} P Q_{d d}
$$

If the countries instead form a customs union, distortion due to the common external tariff is:

$$
\left(\frac{t_{a}+t_{b}}{2}\right)^{2} P Q_{d \quad d}
$$

It is straightforward to show that for the case where elasticities are constant and countries' markets are identical, distortion is less when tariffs are averaged. This is simply because the distortion is proportional to the square of the tariff rate. When tariff rates are averaged, the total distortion is therefore smaller.

It is possible to derive an expression for the common external tariff of a $\mathrm{CU}$ that has equivalent distortion to an FTA where each country maintains its previous tariffs. If elasticities are not constant, distortions due to a common external tariff are equivalent to those from an FTA when the common external tariff $\left(t_{c}\right)$ is set so that it equals:

$$
\sqrt{\frac{d a}{2_{d c}} t_{a}^{2}+\frac{d b}{2_{d c}} t_{d}^{2}}
$$

where $\varepsilon_{-\mathrm{dx}}$ is the elasticity of import demand when the tariff is set at $t_{\mathrm{x}}$. In most cases, this distortion equivalent tariff will be greater than if the tariffs had been simply averaged. However, if the elasticity of import demand is much smaller at higher tariff levels than at lower tariff levels, this conclusion could be reversed. ${ }^{6}$

5. These expressions assume that imports are coming from the rest of the world, not the partner country, in order to examine only the effects of the external tariff on trade with the rest of the world. Including trade with the partner country would introduce typical trade creation and trade diversion effects, but would not affect the issue analyzed here. Also, I assume that all trade occurs in final goods. In the following section, the consequences of relaxing this assumption will be tackled. 
Under the assumption of constant elasticities, this expression simplifies to:

$$
\sqrt{\frac{t_{a}^{2}+t_{b}^{2}}{2}}
$$

This is a higher tariff rate than if the tariffs had been simply averaged.

This point can be seen very easily in the following diagram. When countries $a$ and $b$ (that have identical import demand curves) average their tariffs on imports from the outside world, the resulting deadweight loss is shown by the areas $2 B+2 C$. When the countries maintain their initial tariff rates, resulting deadweight loss is equal to $A+B+2 C$. If $A>B$, distortion is less with a customs union.

Figure 1

\section{Deadweight Loss in a CU and a FTA}

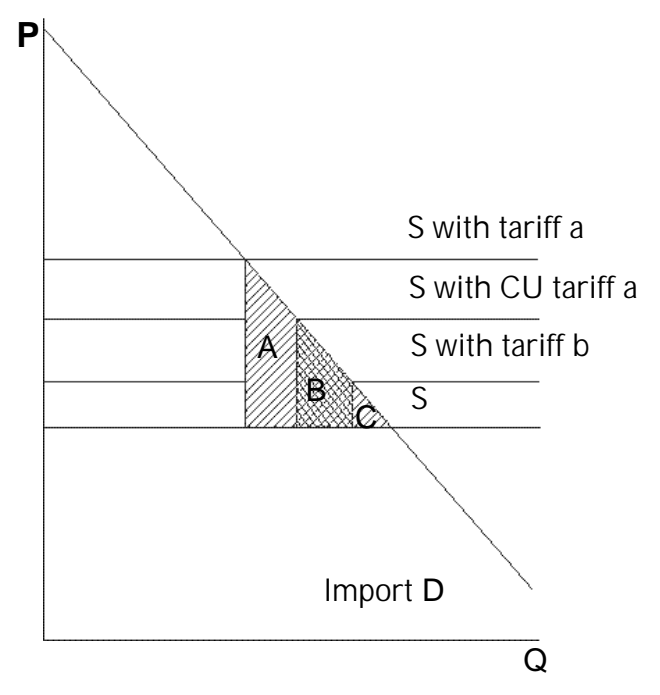

6. For example, if $\mathrm{t}_{\mathrm{a}}>\mathrm{t}_{\mathrm{b}}$ and $\varepsilon_{\mathrm{da}}<\varepsilon_{\mathrm{db}}$, then the weight on the higher tariff in this equa 
Of course, this simplified analysis is only pertinent under certain assumptions. First of all, when some tariffs are greater than the prohibitive level (i.e., there is "water" in the tariffs), this will affect the trade-offs between customs unions and free trade areas. For example, if one country has twice the tariff required to be prohibitive, and the other no tariffs, then averaging tariffs would be inferior to the outcome under a free trade agreement. Second, when some countries have much larger amounts of trade than others (e.g., the United States vs. Canada), it is important to weight the tariff averages accordingly. The trade weighted average tariff is a more appropriate concept than an unweighted average. ${ }^{7}$ Third, in order to more thoroughly examine how the level of protection will change under a CU or FTA, factors such as the level of input tariffs and the effect of rules of origin need to be reckoned with. The next section will turn to these issues.

\section{Rules of Origin}

Rules of origin (ROOs) specify a requirement that must be met in order for a particular good to originate in a given country or area, and hence to receive preferential tariff treatment. Rules of origin are necessary in free trade agreements in order to allow countries to maintain separate external tariffs. Without rules of origin, free trade agreements would simply become equivalent to customs unions where the common external tariff was equal to that of the lowest member country (abstracting from transportation costs) ${ }^{8}$

tion is reduced relative to the weight on the lower tariff. If $\varepsilon$-da is sufficiently small relative to $\varepsilon$ db then the common external tariff equivalent in distortion to the FTA alternative will be less than had tariffs simply been averaged. On the other hand, if import demand becomes more elastic at higher prices, this strengthens the case for tariff averaging. In fact, this case may be more plausible since reductions of high or prohibitive tariffs may release a lot of stifled import demand.

7. In fact, that is how Article XXIV is typically interpreted (see footnote 4 above). Still, trade weighted tariffs are not perfect either, since trade will be lower precisely when tariffs are higher. However, a trade weighted average tariff would bias the common external tariff downward, a desirable result.

8. Although this section assumes that rules of origin are necessary in FTAs but absent 
K rueger (1997) has argued that the effects of rules of origin are detrimental to welfare, such that, other things equal, customs unions are welfare superior to free trade agreements. Krueger's argument is based on the potential for exported protection due to rules of origin. Beginning with several assumptions ${ }^{9}$, the following conclusion is derived: "an FTA cannot lead to more trade creation than can a customs union and, when ROOs export any protection, an FTA leads to more trade diversion than does a customs union." 10

Let's further examine this argument. The first premise of the argument is straightforward: an FTA can not lead to more trade creation than a CU since trade creation merely depends on removing barriers between partner countries, and that is done under either arrangement. The second premise is that FTAs lead to more trade diversion than CUs due to rules of origin. The idea behind this premise is clear: since rules need to be satisfied in order to gain tariff preference, this biases producers in member countries toward using inputs from within the agreement, rather than sourcing from the most efficient source. Thus, if Canada and the U nited States have an FTA, a Canadian widget producer may be inclined to use Canadian or U.S. inputs that are more expensive than those from a third country in order to satisfy the ROO and export to the United States duty free. This is true even when the Canadian widget producer faces no tariffs on widget inputs in Canada.

Consider the maximization problem that a North American producer

in CUs, rules of origin are often utilized in customs unions as well. For instance, "the EC was the pioneer of using rules of origin as a trade policy tool to encourage EC content, EC sourcing, and hence investment in EC manufacturing facilities throughout the creation of the Single M arket in 1989-1992". (J ensen-M oran(1995)). One classic example of such a strategy was the use of ROOs to encourage investment in semiconductor manufacturing. Originally, semiconductors assembled in the EC were considered of EC origin, and thus not subject to the 14\%tariff. After 1989, however, a new rule was put in place that required diffusion to be preformed in the EC to confer origin, and thus avoid the tariff.

9. Specifically, Krueger ((1997), p.180) assumes that "effective rates of protection are not increased under a customs union, there is no 'water' in either country's tariff schedule, and that cost curves are either constant or upward sloping."

10. See Krueger ((1997), p.180). 
would face:

$$
\operatorname{Max} P F(M, D)-\left(p_{w} M+p_{d} D\right)
$$

where

$$
\begin{aligned}
& P=\frac{1}{(1+T)} \text { if } p_{w} M>(1-\quad)\left(p_{w} M+p_{d} D\right) \\
& P=1 \text { if } p_{w} M \leq(1-\quad)\left(p_{w} M+p_{d} D\right)
\end{aligned}
$$

Here $P$ is the final price of the product, $M$ is the imported input, $D$ is the domestic (within the agreement) input, $T$ is the tariff on the final product, $p_{w}$ is the world input price, and $p_{d}$ is the domestic input prices. If the ROO is satisfied, the producer receives the entire product price (1); if the ROO is not satisfied, the producer receives the net price $1 /(1+T)$. is the share of inputs that must originate within the agreement to satisfy the ROO.11

When the ROO is just satisfied, the Lagrangean for the producer is:

$$
\begin{aligned}
L= & P F(M, D)-\left(p_{w} M+p_{d} D\right)- \\
& {\left[p_{w} M-1(-)\left(p_{w} M+p_{d} D\right)\right] }
\end{aligned}
$$

The first order conditions are then:

$$
\begin{aligned}
& \text { 1. } P F_{m}=P_{w}(1+\quad) \\
& \text { 2. } P F_{d}=P_{d}(1-(1-)) \\
& \text { 3. } p_{w} M=(1-\quad)\left(p_{w} M+p_{d} D\right)
\end{aligned}
$$

11. Note that, in this model, I am focusing on ROOs that specify a given content requirement that must be satisfied in order for the rule to be met. As footnote 2 notes, this is just one type of ROO, but it is much simpler to analyze this type of ROO than the others. Krueger and Krishna (1995) also focus on this type of ROO since, as they note, "From an analytical point of view the legal classification makes little sense...We chose to focus on (a) [domestic content-type ROOs] since we have little to say about (b) [those that require specific transformation steps] other than that it must raise costs." 
From these conditions, it is clear that when a producer chooses to satisfy a binding ROO, that ROO acts as a tax of $\mathrm{p}_{\mathrm{w}}$ on $\mathrm{M}$ and a subsidy of (1- $) p_{d}$ on $D$. In that respect, it is clear that a rule of origin favors inputs produced within the agreement over those imported. This is the sense in which rules of origin can lead to protection for inputs even when protection did not previously exist. ${ }^{12}$

However, while it is certainly the case that an FTA without ROOs is preferable to an FTA with ROOs, the difference between a customs union and an FTA with ROOs is ambiguous. Consider a preferential trading agreement between two countries, one of which has a tariff ( $t$ ) on input goods, and one of which has no tariff on inputs; both have a tariff $(T)$ on the output good. The country without the input tariff produces the final product, importing parts from abroad. A free trade agreement with a binding rule of origin provides two options. Producers can use the most efficient parts sources worldwide, and receive $P /(1+T)$. Or, producers can receive the tariff inclusive price $P$, by choosing to satisfy the ROO ${ }^{13}$. If the ROO is just satisfied,

$$
p_{w} M=(1-\quad)\left(p_{w} M+p_{d} D\right)
$$

So producers will use the imported input (M) and the domestic (within region) input (D) in the following ratio, where (is the domestic content required by the ROO.

$$
\frac{M}{D}=\frac{1-}{p_{w}}
$$

Since the input is protected by a tariff in the partner country, $p_{d}=p_{w}(1+t)$, where $t$ is the tariff on the imported input. ${ }^{14}$

12. This analysis is derived from Grossman (1981). It can be extended to include nontraded goods or value added, without changing the results of interest.

13. For now, assume the ROO is binding, so the producer chooses to satisfy the ROO exactly. In general, the level of the tariff preference on the final good will be important in determining whether producers find it worthwhile to distort their behavior in order to comply with the ROO, and thus in determining the ultimate impact of the ROO.

14. It is assumed that $D$ and $M$ are perfect substitutes, and that the only additional cost 
Let's compare this situation to that under a customs union. A customs union (assuming tariff averaging) allows producers to use the most efficient parts sources but not tariff-free. So producers pay $\left(p^{w}+t / 2\right)$ for parts. I will now demonstrate that the level of content required by the ROO ( ) and the level of input tariffs ( $t$ ) determine whether the FTA or the CU leads to more input protection (and therefore a higher cost of inputs in the final product). Under the condition that

$$
D P_{w}(1+t)+M P_{w}>(M+D) P_{w}\left(1+\frac{t}{2}\right)
$$

input prices will be higher in a free trade agreement than in a customs union. Signify the (fixed) total inputs required by $F$, so that $M+D=F$. Plugging in the ratio of domestic to foreign inputs used to just satisfy the ROO, one can write expressions for $M$ and $D$ as a share of $F$ when the ROO is satisfied under an FTA:

$$
M=F \frac{(1-\quad)(1+t)}{+(1-\quad)(1+t)}, D=F \frac{}{+(1-\quad)(1+t)}
$$

Using these expressions, one finds that input prices are higher with a free trade agreement if:

$$
\frac{F P_{w}(1+t)}{+(1-)(1+t)}+\frac{F(1-)(1+t) P_{w}}{+(1+\quad)(1+t)}>F P_{w}\left(1+\frac{t}{2}\right)
$$

Rear ranging, this condition is satisfied if:

$$
\overline{(1-)}>(1+t)
$$

To take a simple example, if $t=1 / 2$, a rule of origin of $60 \%$ would lead to equivalent levels of input protection in both the FTA and CU cases. A less restrictive ROO would lead us to favor FTAs, a more restrictive ROO, CUs.

of satisfying the ROO is paying the tariff inclusive price for the inputs. To the extent that $D$ is an imperfect substitute for $M$, or that local content is more expensive than the tariff inclusive price of imported inputs, it will be more costly to comply with the ROO. 
For the above example, if is less than $50 \%$ the FTA will lead to lower input prices than a CU. If is greater than $2 / 3$, the $\mathrm{CU}$ will lead to lower input prices. ${ }^{15}$ In between these two boundaries, the level of the tariff will matter as well as the level of .

Krueger's finding that (other things equal) ROOs make customs unions welfare superior to free trade agreements partially stems from the assumption (relaxed here) that external protection remains the same for customs unions, while external protection may increase in free trade agreements as parts protection is created by the ROO. Still, the non-uniformity of external tariffs under an FTA provides an opportunity as well as a cost. ROOs discourage the use of foreign inputs, but when the ROO is not too strict, low cost foreign inputs can still enter the high tariff country embodied in the final products of the low tariff country.

The above analysis has assumed that the ROO is binding. In reality, there are three possibilities. First, the ROO may not be binding: producers may already be profitably using enough domestic content to avoid altering their production decisions to qualify for the ROO. In this case, one does not have to wor ry about the parts protection effect. Second, the ROO may lead producers to alter parts sourcing in order to qualify for tariff free treatment: this is the case discussed above. Finally, the ROO may be so costly to meet that producers decide to pay the tariff rather than distorting their sourcing decisions sufficiently to satisfy the Ro0. ${ }^{16}$ In that case, the potential trade creation gains may be significantly smaller than those were the agreement a customs union. ${ }^{17}$

Two clear conclusions emerge from this analysis. First, rules of origin act to increase protection from what it would be in the absence of rules of origin. Thus, to the extent possible, they should be discouraged. This impor-

15. Assuming a maximum tariff of $100 \%$

16. This may occur, not only because sourcing within the agreement is costly, but also because of the (non trivial) administrative cost associated with meeting the rule.

17. In addition, as Krueger and Krishna (1995) discuss, the form the ROO takes may be important for understanding its effects, as well as the structure of the markets affected. This later point was also discussed in Lopez-de-Silanes, M arkusen, and Rutherford (1993). 
tant point has already been well demonstrated by Krueger $(1993,1997)$. In practice, the creation of ROOs requires a balancing act. In order to create an FTA where members are able to maintain their previous trade policies, it is necessary to have some ROOs. If ROOs are too lax, high tariff member countries will be unwilling to join the agreement due to the potential for transshipment. Too strict ROOs, however, can lead to exported protection and even reduced trade creation gains.

Second, from the standpoint of one who wants to minimize protection, one can not unambiguously prefer a customs union without rules of origin over a free trade area with rules of origin. The overall effect on protection will depend on how strict the rules of origin are. For sufficiently loose rules of origin, a free trade agreement may lead to an outcome that is in fact preferable to a customs union.

In the extreme example, if one considers a very loose ROO, it is clear that a free trade agreement will act to export liberalization from the lowest tariff country to those with higher tariffs. On the other hand, a very tight ROO could act to export protection, by acting as a tax on imported inputs, and may even be sufficiently strict to eliminate some of the trade creation resulting from the tariff liberalization between the member countries. Somewhere in between there exists a ROO such that the degree of liberalization occurring with a free trade agreement is similar to that occurring within a customs union. Whether the ROOs present in current agreements are more or less stringent than that level, however, is an empirical question. ${ }^{18}$

18. Several authors have suggested ways to get around the adverse effects of rules of origin in free trade agreements. Lloyd (1993) suggests a tariff that varies according to the share of foreign content. While this sort of instrument would eliminate the arbitrary nature of rules of origin and would meet the policy objective of discouraging transshipment, it would not address the problem of exported protection discussed above. Rather, it would act directly to tax foreign content in the same manner that an arbitrary ROO was shown to do above.

Davis (1995) tackles the losses due to exported protection directly. He proposes a third technology available to producers, in addition the options of complying with the ROO or paying the tariff. This technology is a penalty for violating ROOs equal to $(r-\varepsilon) d \alpha$ where $d o$ is the firm's choice of the amount by which to violate the ROO, $r$ is the (rising) cost to the firm of complying with the ROO, and $\varepsilon$ is some small amount. 


\section{Political Economy Considerations}

The decision between a CU and an FTA may also influence the future of multilateral liberalization for political economy reasons. First, the manner in which the common external tariff is set in a customs union may be important for the future of multilateral liberalization. Both Bagwell and Staiger (1997a,b) and Sinclair and Vines (1995) emphasize the fact that CUs augment market power, and conclude therefore that FTAs will have more benign effects on external protection. On the other hand, Panagariya and Findlay (1996) argue that common external tariffs under CUs are likely to be lower than average protection levels under FTAs. This is because of a free rider effect: protection in an FTA is a private good, while in a CU it becomes a public good. ${ }^{19}$

Second, FTAs and CUs differ in the ability of policy makers to respond to incentives to alter trade barriers. Leamer (1994), Richardson (1993), and Wonnacott and Lutz (1989) have all emphasized the incentive to lower external tariffs endogenously in an FTA. As imports from partner countries replace imports from the rest of the world, this creates an incentive to lower tariffs on goods from other countries. Since the domestic industry presumably does not care from what source the imports come, the government has an incentive to lower tariffs in order to convert deadweight loss to tariff revenue. The same incentives occur for members of both customs unions and free trade agreements, but members of customs unions are less able to act on it. ${ }^{20}$ The common external tariff is already agreed upon, and thus difficult

Through this mechanism, firms can avoid distorting their input decisions, countries can maintain their differential tariff rates, and deadweight loss can be converted to tariff revenue.

19. For instance, if lobbying is done by agents of one country's producers, they will need to invest more resources under a CU than in an FTA to obtain the same tariff level, and a tariff granted to one country will be granted to all member countries.

20. There are also two reasons why an FTA may lead to increased incentives to lower protection relative to a CU. First, firms have an incentive to invest in countries with low tariffs on imported inputs. This will encourage the member countries to higher input tariffs to lower them. Secondly, as Davis (1995) notes, ROOS create an incentive to reduce multilateral tariffs that will be politically sustainable. A small reduction in tariffs will bring about two effects. For the group of producers that is paying the 
to change. ${ }^{21}$

Third, the ability of FTAs and CUs to expand to include new members differs. Some have argued that FTAs expand more easily than customs unions. New members need not alter their external tariffs, since they are not required to adopt the common external tariff. However, joining an FTA is not a simple matter either, due to the added complication of rules of origin. As more countries join, the ROO becomes easier to satisfy. This may lead to political pressure to strengthen the ROO. As discussed above, the more restrictive the ROOs, the more likely they will act to export protection, and the more likely FTAs will be inferior to CUs. As CUs expand, new members adopt the common external tariff. The effect of adopting a common external tariff, relative to joining an FTA, will depend on the tariff structure of the new members. When new members predominantly have higher tariffs than the agreement members, a CU is clearly preferable; when the opposite is the case, an FTA is likely to be preferable.

\section{Conclusions}

This paper has analyzed a number of trade-offs that determine the relative merits of customs unions and free trade areas. Two noteworthy findings have been demonstrated. First, when the common external tariff under a customs union is set at the average of the member countries' previous tariff levels, it is likely to lead to a less distortionary outcome than if the member countries had maintained their prior tariff levels. While this conclusion is

tariff rather than comply with the ROO, a small tariff reduction will improve welfare. For the group of producers that finds the ROO most difficult to satisfy yet choose to satisfy the ROO, the tariff reduction will lead them to pay the tariff instead. This converts deadweight loss to tariff revenue for those producers for whom the ROO created the largest deadweight loss.

21. Trade creation also creates an incentive to change external tariff barriers. As partner imports replace domestic production, this hurts domestic producers. This encourages them to lobby for more protection. Since the preferential agreement constrains the government to not raise barriers on the partner country, there is an incentive to instead raise barriers on imports from the rest of the world. Although this action is not allowed under Article XXIV of the GATT, this rule is difficult to enforce, and does not pertain to administered protection. 
true under standard assumptions, one should also consider the extent to which member countries have "water" in their tariffs and the method used to determine the average common external tariff.

Second, rules of origin act to distort input decisions, and should therefore be minimized. However, a free trade agreement with ROOs is not necessarily inferior to the customs union alternative. The ranking of the two arrangements will depend on the restrictiveness of the ROOs as well as the tariff levels among the member countries.

In determining the relative merits of FTAs and CUS, it is also important to evaluate political economy considerations. FTAs allow member countries to lower their trade barriers without considering the potentially conflicting interests of partner countries. However, FTAs also allow countries greater flexibility to raise barriers against non-members. As countries join existing agreements, one should pay close attention to how ROOs evolve in FTAs, and how the common external tariff in a $\mathrm{CU}$ differs from that of the acceding country.

It is not possible to offer an endorsement or a condemnation of either arrangement. However, there are a number of essential factors to consider when determining which arrangement is optimal. On the whole, a customs union with a low common external tariff is administratively simple and would usually be preferred to an FTA that introduced a myriad of complex ROOs. In particular, the anecdotal evidence on this subject has emphasized the high compliance costs and administrative burdens associated with ROOs. If a customs union is decided upon, it is important to encourage a low common external tariff that is flexible downwards.

It is quite possible that a free trade area will be (politically) feasible in instances where a customs union would not be. For instance, countries may be unable to agree on a common external tariff. In such cases, this paper points toward factors to consider in order to make a free trade area compatible with free trade. Foremost, it is important to ensure that ROOs are not too strict. M ost rules should and could be designed to avoid transshipment without unduly distorting production decisions. For instance, the ROOs that require a simple change in tariff classification are likely to fit this criteria.

This paper has indicated that the relative merits of free trade areas and customs unions depend to a large extent on how these agreements are car- 
ried out in practice: how tariffs are set and how rules of origin are defined. These empirical questions provide an extensive agenda for future research.

\section{References}

Bagwell, K. and R. Staiger (1997a), M ultilateral Tariff Cooperation During the F ormation of Customs U nions, Journal of International E conomics 42 (1-2); 91-123.

Bagwell, K. and R. Staiger (1997b), M ultilateral Tariff Cooperation During the Formation of F ree Trade Areas, International E conomic Review 38 (2); 291-319.

Davis, D. (1995), Comment, in J. Levinsohn, A. Deardorff, and R. Stern, eds., New Directions in Trade Theory (U of Michigan Press, Ann Arbor).

Grossman, G. (1981), "The Theory of Domestic Content Protection and Content Preference," Q uarterly J ournal of E conomics 96(4); 583-603.

J ensen-M oran, J. (1995), "Trade Battles as Investment Wars: The Coming Rules of Origin Debate," Washington Quarterly 19 (1); 239-253.

Krishna, K. and A. Krueger (1995), "Implementing Free Trade Areas: ROOs and Hidden Protection, in J. Levinsohn," A. Deardorff, and R. Stern, eds., New Directions in Trade Theory (U of Michigan Press, Ann Arbor).

K rueger, A. (1999), "Free Trade Agreements as Protectionist Devices:

Rules of Origin," in M elvin et al, eds., Trade, Theory and E conometrics (Routledge, London); 91-102.

Krueger, A. (1997), "F ree Trade Agreements versus Customs Unions, Jour -

nal of Development E conomics 54, 169-187.

Leamer, E. (1994), American Regionalism and Global Free Trade, NBER Working Paper \#4753, M ay.

Lopez-de-Silanes, F., J. M arkusen, and T. Rutherford (1993), "Anti-Competi-

tive and Rent-Shifting Aspects of Domestic-Content Provisions in

Regional Trading Blocks," NBER Working Paper N 0. 4512, October.

Lloyd, P.J . (1993), "A Tariff Substitute for Rules of Origin in Free Trade Areas," World E conomy 16(6); 699-712.

Panagariya, A. and R.F indlay (1996), "A Political Economy Analysis of Free 
Trade Areas and Customs Unions, in Feenstra," Grossman, and Irwin, eds. The Political Economy of Trade Policy: Essays in Honor of Jagdish Bhagwati (MIT Press, Cambridge).

Richardson, M. (1993), "Endogenous Protection and Trade Diversion." Journal of International E conomics 34; 309-324.

Sinclair, P. and D.Vines (1995), Bigger Trading B locs Need N ot Entail M ore Protection, photocopy, October.

Wonnacott, P. and M . Lutz (1989), Is There a Case for Free Trade Areas?, in Schott, ed., Free Trade Areas and U.S. Trade Policy (Institute for Intl. Economics, Washington).

World Trade Organization (1995), Guide to GATT Law and Practice Volume II (World Trade Organization, Geneva). 